\title{
RNF213 Gene
}

National Cancer Institute

\section{Source}

National Cancer Institute. RNF213 Gene. NCI Thesaurus. Code C97390.

This gene may be involved in ubiquitination. 